\title{
Internalization of Entrepreneurship Values For Entrepreneurship Learning in Vocational Schools
}

\author{
Khairuddin E. Tambunan ${ }^{1}$, Sri Umi Mintarti $\mathrm{W}^{2}$, Wahjoedi ${ }^{2}$, Hari Wahyono ${ }^{2}$ \\ ${ }^{1}$ Doctorate Student of Economics Education, Universitas Negeri Malang, and Faculty of Economic, \\ Universitas Negeri Medan, \\ ${ }^{2}$ Universitas Negeri Malang, \\ INDONESIA \\ irol_t@yahoo.com; sri.umi.fe@um.ac.id; wahjoedi.fe@um.ac.id; ayong@um.ac.id
}

\begin{abstract}
The main purpose of this study is to determine the implementation of internalization, the effectiveness of internalization, the impact of internalization and government support in internalizing entrepreneurship values for entrepreneurship learning in Vocational Schools. This research uses a qualitative approach, with data collection tools in the form of interviews, observations and questionnaires. The study population is the eleventh grade students at Vocational School in Medan, North Sumatra. The research sample is eleventh grade students of marketing and office administration that are determined based on purposive random sampling.

The results showed that internalization of entrepreneurial values is important to be applied in entrepreneurship learning because: (1) it is able to improve the quality of learning and student involvement in the learning process, (2) improving the competence and skills of students or graduates in developing self-potential and (3) changing students' attitudes and behavior in the learning process and daily life. Data material only includes 2 vocational schools in medan city, north sumatra province. Further studies are needed in increasing the number of students and larger vocational schools. In addition, expanding the internalization of entrepreneurial values in entrepreneurial learning activities. Qualitative research must consider a greater number of student and school involvement, because this is related to the extent of the validity of the data produced. At the same time, there is an urgent need to internalize entrepreneurial values in learning to provide provisions for students to enter the labor market.
\end{abstract}

Key-words: Internalization, Entrepreneurship, Entrepreneurship Values, Entrepreneurship Learning, Received: October 6, 2020. Revised: December 30, 2020. Accepted: January 6, 2021. Published: January 20,

\section{Introduction}

The phenomenon that there is high unemployment rate of vocational graduates has placed crucial problem in the education world in Indonesia. The Central Bureau of Statistics (BPS), reported that in 2017 the unemployment rate in Indonesia from vocational graduates at the level of 11.41 percent and was the highest unemployment rate among graduates who had a degree. One reason for the high unemployment of SMK graduates is the low expertise of vocational graduates compared to high school graduates. This explained that the soft skills of vocational graduates on a national average are below high school graduates. These abilities can be seen from the way students understand their own psychological conditions, regulate speech, thoughts, and attitudes and behaviors according to their environment.

Research conducted shows that there are five values that need to be given to entrepreneurship subjects such as: entrepreneurial mentality; innovation; looking for business ideas / ideas; face risks; and marketing [1]. Furthermore, [2] states that entrepreneurial values instilled in vocational students are the value of faith and devotion, the value of discipline, honesty values, prestige work behavior which includes sincere work, smart work, self-awareness of emotions, hard work and complete work, creativity and innovation, confidence and responsibility.

Thus, this research provides an overview for research relating to entrepreneurial values. Furthermore, according to [3] stated that the implementation of entrepreneurship education in 
vocational high schools can be done through one subject or integrated in other subjects.

The success of entrepreneurship learning in schools is strongly influenced by the quality of learning. Where entrepreneurship learning is a program to recognize the concept of entrepreneurship, practice business development, gain practical experience in entrepreneurship, foster entrepreneurial interest and develop potential entrepreneurial spirit in students. Therefore, learning in schools must be an alternative in preparing vocational school graduates who are able to create jobs and be able to adapt to social life. For this reason, internalizing entrepreneurial values for students in vocational schools is important, so that they have the means to enter the labor market.

\section{Theoritical Study}

\subsection{Internalization}

Internalization is a process by including ideal values or attitudes that were previously considered to be outside, so that they are incorporated into a person's thinking that is life skills and attitudes. To mentioned three events in the process of building knowledge, including in the learning process in the classroom [4]. These include: externalization, objectification and internalization. Thus internalization is part of various efforts of knowledge carried out through a model, method, even technical method. Internalization is lifelong learning which is carried out by a person or community group. Learning in the form of absorption of rules in society, values, and norms, actions taken by a person through practice with awareness, which will form a custom or habit in a person. Meanwhile, to the explained that internalization is the cultivation of a person's behavior, attitudes, and values which he gets in the process of coaching, learning, and guidance.

Internalized an individual process of learning and receiving into a part, and at the same time binds itself to the values and social norms of the behavior of a society [5]. On the other hand, internalization is a process by uniting cultural values and expectations with a personality system [6]. States that internalization can affect someone in behaving, feeling, believing. That happens from the process of absorbing an experience, action or repeated speech.

Based on the opinion above, internalization is a process of learning for someone so that a person can receive a part of society, which then binds itself to the values and social norms of group behavior in the community. Thus internalization is a process of understanding by individuals in involving ideas, concepts and actions contained from the outside then moves into the mind of a personality until the individual concerned accepts that value as the norm he believes in, and becomes part of his views and moral actions.

\subsection{Entepreunership Values}

Value can be defined as the recommended quality because it will have an impact on the choice of objectives, means and methods available, and is used as a criterion in assessing various phenomena. Suggests that value is something abstract, which is used as a guide and general principles in acting and behaving [7].

Expressing value is a reference and confidence in making choices [8]. This explains that values are beliefs that can be generalized and function as a guiding line to select the objectives to be chosen to be achieved. Argues that value is an idea that belongs to a person or group about what is feasible, what is desired, and what is good and bad [9]. Whereas, suggested that value is an idea about whether an action is important or not important [10].

Furthermore, stated that value is an cumulative idea (collectively) about what is considered important, good, feasible and desired by someone. This is at the same time about what is considered insignificant, bad, inappropriate and undesirable in terms of culture. Entrepreneurship values are prerequisites related to entrepreneurial behavior [11]. These values consist of creativity, risk taking, innovation, achievement oriented, ambition, and independence.

Value in running a business contains elements of consideration that develop personal or social ideas/ideas. Values form the basis for understanding attitudes and motivations, where values can influence perceptions of behavior in 
conducting business, so values are very important to learn in managing organizational behavior [12]. Entrepreneurship values are internalized in entrepreneurial learning that is: 1) honesty, 2) creative, 3) innovation, 4) risk taking, 5) cooperating, 6) responsibility, and 7) forwardlooking.

\subsection{Entrepreneurship Learning}

Entrepreneurship learning is a process of cultivating and developing as well as an effort to instill and strengthen one's mental readiness, so that they have enthusiasm in creating or carrying out activities. The real effort to develop entrepreneurial attitudes can be started by making it properly and more radical education planning [13].

Entrepreneurship learning can be developed by preparing the community for success in the entrepreneurial economy. This happened because the economy experienced a transition, so that entrepreneurship learning became an integral part of the new curriculum offered by both private and public schools.

Furthermore, explained that entrepreneurial development potential is strongly influenced by motivation, values, skills, learning, relationships, and desired targets [14]. Whether or not entrepreneurial learning is effective, learning must carry out activities in entrepreneurial ways. For this reason, even though it is done in a learning class, knowledge factors are an important aspect, and not enough just aspects of traditional knowledge. On the other hand argues that entrepreneurial learning is part of an educational program that employs entrepreneurial aspects as an important part of debriefing student competencies [15]. This process has dual connotations in learning to behave, and learning through entrepreneurial means. Learning must be relational, authentic, relevant, useful and productive.

According to entrepreneurial learning is a process that facilitates the development of the knowledge needed to be effective in starting and managing new businesses [16]. Thus, entrepreneurial learning can be interpreted as a process of individual experience continuously developing entrepreneurial knowledge throughout professional life. Entrepreneurship learning can be considered as a process of experience in which business people develop knowledge through four distinctive learning abilities: experiencing, reflecting, thinking, and acting [17].

From the description above, entrepreneurship learning is a process in which people acquire, assimilate, and regulate newly formed knowledge with pre-existing structures, and how learning influences entrepreneurial actions.

\subsection{Vocational High School}

Vocational education includes every form of education that aims to obtain qualifications related to profession, art or certain occupations. In addition, vocational education provides the necessary training and skills that are in line with technical knowledge, so students can be used according to the profession. According to vocational education is a part of the education system that prepares a person to be better and able to work in one work group or one occupational field than in other occupational fields [18].

Vocational education includes a comprehensive education framework. However, vocational curriculum has certain characteristics that distinguish it from other education.Vocational education is considered as a solution to improve opportunities that lack the resources, skills or motivation to continue to race even higher. Thus, vocational schools can provide skills that are useful for preparing graduates to enter the workforce and enhance successful professional career opportunities [19].

For this reason, vocational schools must meet the requirements relating to values in society that are: civilization of vocational values such as; (1) development of individual cognitive and psychomotor abilities [20]; (2) attitude development [21]; (3) developing a positive appreciation for work, building a work culture [22], building a learning culture, innovative culture, creative and productive [23]; (4) preparing students for work, entrepreneurship, or going forward [24]; (5) empower students to get decent jobs and income [23]; (6) career development in accordance with competence; (7) 
facilitating the fulfillment of all students' physical and non-physical, moral, and future needs of a comfortable, safe and happy society [25]; and (8) involve stakeholders widely, intact, true and responsible [26].

\section{Methodology}

This research is qualitative research using descriptive case studies. The qualitative methods as a particular tradition in social science are fundamentally dependent on observing humans in their own fields and dealing with these people in their language and terminology. According to case studies can explain in detail and comprehensively about the characteristics, and how and why characteristics of cases can be formed [27].

The study was conducted in Medan, North Sumatra and in the odd semester of TP 2017/2018. The sample size of this study was collected based on proportional random sampling. This study uses qualitative methods and data obtained through interviews, observations and questionnaires and data collected, analyzed using descriptive analysis.

\section{Research Findings (Result and Discussion) 4.1.Internalization of Entepreunership Value}

Based on the results of the study, it was found that there was a need to internalize entrepreneurial values for vocational students in entrepreneurial learning activities. This can be seen from the conventional learning method. This condition will have an impact on the low quality or competency of graduates produced. Besides that, entrepreneurship learning has not included entrepreneurial values in the learning process, so students do not understand the meaning and function of values in learning. For this reason, efforts to internalize values in entrepreneurial learning activities are needed. This is in accordance with research that there is a relationship between creativity, innovation and entrepreneurship [28]. This shows that the importance of creativity and entrepreneurship in learning activities to achieve the expected competencies. Furthermore, states that factors of innovation, creativity, and entrepreneurship together improve education and career success. Thus, entrepreneurial learning activities require innovation and creativity which is carried out not only to fulfill economic reasons, but because of the demands of work.

Internalization of entrepreneurial values is an effort to provide students with supplies in the form of understanding and knowledge of values. In line with stated that internalization is the merging of values in a person or is an adjustment to the beliefs, values, attitudes, practices and rules of the standard in a person [29]. Thus, understanding the values obtained must be practicable and have implications for attitudes that are permanent in a person.

The description above also confirms typical entrepreneurship in Slovakia as a person who has moral in accordance with his wisdom, and most respects honesty, dedication, legal compliance, expertise, dependence, perseverance, and the like. Most realize that organizational values and moral virtues are the conditions needed for a successful business. In several studies showing entrepreneurial learning leads to conceptualization learned through entrepreneurial experience and learning needs to be seen as a practice method, where knowledge is developed and formed in the process of experience of literacy and social dynamics.

For this reason, internalization of entrepreneurial values is based on practice-based learning. Currently, the learning still emphasizes the technical form of education that emphasizes knowledge aspects. Practice-based learning and education allows students to explore learning experiences. Therefore the process of internalizing values is a process of reconstruction of values and adjustments to values. For that, in an effort to provide provisions for students or graduates, entrepreneurial values are internalized in the learning process that is: honesty, creative, innovation, risk taking, responsibility, and cooperation and forward-oriented.

\subsection{The Effectiveness of Internalization for Entepreunership Value}

Education as a potential source for competitiveness, the effectiveness must be considered especially with regard to the type of education offered, the approach used, and the 
involvement of students in the teaching and learning process. The results of the study indicate that the internalization of entrepreneurial values is effective in entrepreneurial learning. This can be seen from the increase in students' understanding and knowledge of entrepreneurial values taught. In addition, changes in attitudes and behavior of students in following the learning process.

Various studies were conducted to explore the way students learn by considering whether the current method of teaching is the best approach in meeting the needs and learning styles of students. Where the next discussion is how students' attitudes toward learning have shifted from the view of education as an intellectual challenge and see values in knowledge being goal-oriented. This is very much influenced by pressure, work ambitions, and the desire of students to see the benefits of the values learned. Of course this will raise doubts about the learning process with a teacher-focused pedagogical approach.

In accordance with the results of the study, it requires student involvement in the learning process. Students must be given space and opportunity to express the knowledge they have and apply in the learning process. For this reason, teachers need to be able to help students express their knowledge and learning experiences according to their abilities and competencies. To achieve learning effectiveness it is possible to apply learning methods and models that are more practical, relevant, independent, and motivate students.

To support the effectiveness of implementing entrepreneurship learning, teachers need to understand aspects of entrepreneurial attitudes, and more effective entrepreneurship teacher education and training programs. Thus, to achieve effectiveness and enthusiasm for entrepreneurial learning, it is possible for teachers to teach entrepreneurship by using innovative and challenging methods in teaching entrepreneurship. Teachers can also improve learning content and teaching methods that are more in line with student learning needs.
For this reason, in teaching entrepreneurship for entrepreneurs, students first have the desire to become entrepreneurs. If students are taught with entrepreneurship skills, the potential for success in entrepreneurship will also increase, even when faced with a very challenging situation [30]

\subsection{The Effect of Internalization for Entepreunership Learning}

The expected impact of the application of entrepreneurial learning through internalization of values is a change in student attitudes and behavior. The impact can be seen from changes in students' intentions, attitudes and entrepreneurial behavior. Where students will become more understanding of entrepreneurial values and then interested in practicing them by creating employment or entrepreneurship. Therefore, appropriate entrepreneurship learning will have an impact on increasing student aspirations for entrepreneurship and job creation. The other impacts based on the results of the research can be described as follows:

a. The emergence of entrepreneurial attitudes, state that individual views about entrepreneurship are often different [31]. Specifically, values and motivation play an important role in intention and behavior relationships. Thus, entrepreneurial attitudes will influence a person's behavior, and these behaviors will influence attitudes.

b. Increase passion for entrepreneurship

Entrepreneurial passion plays a role in entrepreneurship. Entrepreneurship is related to exploration and exploitation of entrepreneurial opportunities [32]. Entrepreneurship learning is often faced with changes in economic, social and disruption of transformation. For this reason, learning entrepreneurship must be able to adapt to the needs and sustained enthusiasm in seeking opportunities for entrepreneurship, developing innovative products or services, and overcoming resource constraints.

c. The emergence of the desire to become a business actor

Several studies have shown that intention has proven to be an effective predictor of planned behavior. In particular [33], argue that entrepreneurial intentions come from 
feasibility and desires and perceptions of awareness and opportunity, which play a role in each entrepreneurial learning.

d. Opportunities for exploration and exploitation of opportunities

The ability to explore and exploit entrepreneurial opportunities is used as a basis for business success [34]. Information seeking are key to recognizing and exploiting business opportunities. Thus, individuals can learn how to recognize the patterns needed to recognize potential opportunities. This in explains that opportunity discovery, evaluation, and exploitation provide information about the application of entrepreneurial learning techniques.

e. Oriented to independent entrepreneurship

The entrepreneurial orientation and its implications have been of scientific concern in recent years. Most academics view the construction of entrepreneurial orientation as a company-level phenomenon [35]. This can also be applied at the individual level, although some studies have applied this approach.

f. Causing perceptions of self-efficacy

The impact of entrepreneurial learning is related to individual intentions in developing a business [36]. Self-ability refers to individual estimates of the ability to act and success. Self-efficacy is not always about entrepreneurial skills, but rather someone's assessment of the skills they possess. Entrepreneurial images can increase the probability of individuals to consider careers as entrepreneurs, which may have a positive effect on individual self-efficacy.

g. Generating entrepreneurial intentions

Entrepreneurship learning is expected to increase entrepreneurial intentions. The intention is an excuse in preparing for the creation of workplace traffic [37].

h. Improving behavioral control

To assess the impact of a process, intention is a direct determinant of behavior change [38]. Thus, entrepreneurship learning can encourage students to have control over behavior.

\subsection{Government Support}

Government support for the development of entrepreneurship is set forth in various rules such as Law (UU), Government Regulation (PP) and Presidential Instruction (Inpres). Law No. 20 of 2003 concerning the National Education System. Next is PP No. 19 of 2005 concerning the National Education Standards, which provide space for schools and the world of education to formulate a curriculum in accordance with the competence and local needs of the region. Then, PP No. 41 of 2011 concerning the Development of entrepreneurship and youth pioneering and the provision of youth infrastructure and facilities. With this regulation, it gives young people to develop their potential and abilities in developing entrepreneurship. In addition, to support Government Regulation No. 41 of 2011, the Government also issued PP No. 60 of 2013, concerning the organizational structure, personnel, and working mechanism of youth entrepreneurship capital institutions. The PP emphasizes that there is a capital institution for youth in developing entrepreneurship. Thus the development of entrepreneurship is not constrained by capital problems.

To follow up on the previous regulations, in implementing the entrepreneurship the Government issued Presidential Instruction No. 4 of 1995 concerning the national movement to socialize and cultivate entrepreneurship. The presidential instruction mandates all Indonesian people and nations to develop entrepreneurial programs. This illustrates the Government's awareness that the development of entrepreneurial spirit is one form of acceleration in economic development.

In the form of government support for the emergence of the Act, PP and Inpres, the Government issued a policy namely Creative Economy Development in 2010-2014 that is the development of economic activities based on creativity, skills and individual talents to create economic and influential value creation and creativity of individuals on the welfare of the Indonesian people. To make this support useful, it is expected that cooperation and synergy from the regional government and business actors to equip students in accordance with their competencies and skills in the field of 
entrepreneurship. For this reason, the entrepreneurial learning process must internalize values in learning and practice.

In the end, local government programs must be based on policies that are able to reduce the rate of unemployment and break down barriers to be actively involved in economic development. The existence of support in the form of policies and institutional changes will be able to increase the effectiveness of the internalization of values in the process of entrepreneurship learning.

\section{Conclusion and Recommendation}

Based on the explanation above, it can be concluded that entrepreneurial values internalized in entrepreneurship learning in Vocational students include honesty, creativity, innovation, risk taking, cooperation, responsibility and forward-oriented. In addition, the internalization of entrepreneurial values implemented must improve competencies and skills as well as changes in student attitudes and behavior. Furthermore, the internalization of entrepreneurial values is carried out through entrepreneurial learning activities tailored to the needs of students in job creation activities. Thus, the internalization of entrepreneurial values can increase the competitiveness of graduates and reduce the unemployment rate of vocational school graduates as well as increase income and economic growth of the community.

\section{Recommendation}

Based on the results of these studies, it is expected that there will be support from various parties in internalizing entrepreneurial values in entrepreneurial learning. For this reason, cooperation and synergy between the regional government and the school and business actors are needed. The implementation of cooperation and synergy is carried out by combining entrepreneurial values with the value of local wisdom in the region. For this reason, entrepreneurial learning requires improvement or adjustment of the curriculum and improvement of learning facilities and infrastructure in the future.

\section{Acknowledgment}

This research is part of a doctoral dissertation at State University of Malang, Indonesia. As a form of gratitude, I express my gratitude and highest appreciation to the various parties involved in this Research such as Prof. Dr. Sri Umi Mintarti W, SE, MP, Ak ; Prof. Dr. Wahjoedi, ME, and Dr. Hari Wahyono, M.Pd. as a Promotor and Co-Promotor who have given sincere input and direction as well as Principals, Teachers, and Students in Vocational High Schools 1 and 7 Medan who have been willing to provide information and data as a place of research. Besides that, thanks to my parents, my wife and children, brothers and sisters who have given moral support and enthusiasm during this research. I am very grateful to all the great people who have helped in this research.

\section{References}

[1] Rinawiyanti, E. D \& Gunawan, L.H. (2017). "Kajian pembelajaran Kewirausahaan di perguruan tinggi". Jurnal Entrepreneur dan Entrepreneurship, Vol. 4, No.(1) dan (2).

[2] Supriyatiningsih (2012) Penanaman NilaiNilai Kewirausahaan Pada Siswa Melalui Praktik Kerja Industri, Journal of Economic Education ISSN 2252-6889

[3] Jahani (2017) Developing of Entrepreneurial Spirit in the Era of Asean Economic Community in Vocational High School, International Journal of Learning and Development ISSN 2164-4063 2017, Vol. 7, No. 3188 http://ijld.macrothink.org.

[4] Berger, L. Peter \& Luckmann, Thomas. 1966. The Social Construction of Reality. Unites States: Anchor Book

[5] Kalidjernih, F.K. (2010). Kamus Study Kewarganegaraan, Perspektif Sosiologi dan Political. Bandung: Widya Aksara

[6] Johnson, D. P. (1989). Teori Sosiologi Klasik dan Modern. (Di Indonesia oleh Lawang R.M.Z.) Jilid.2, Jakarta: PT Gramedia.

[7] Theodorson, George A, and Achilles G. Theodorson. (1979) A Modern Dictionary of Sociology. New York, San Francisco: Barnes \& Noble Books. Pdf

[8] Allport, Gordon W (2005) Personality: A Psychological Interpretation, New York : Henry Holt and Company dr. Diana, Kamus Kedokteran Lengkap, Surabaya [9] Giddens, Anthony, Politics, Sociology and Social Theory: Encounters with Classical 
and Contemporary Social

ThoughtmStanford University Press, 1 Jan 1995

[10] Horton Paul B \& Chester L Hunt. (1987).

Sosiologi. Jilid I. Diterjemahkan oleh

Aminudin Ram \& Tita Sobari. Jakarta:

Erlangga

[11] Kickul, J., \& K. L. Gundry. (2002).

Prospecting for strategic advantage: The proactive entrepreneurial personality and small firm innovation. Journal of Small Business Management 40 (2): 85-97.

[12] Robbins, S.P. (2007). Perilaku Organisasi. Edisi Bahasa Indonesia Jilid I, Jakarta: PT. Prenhalindo.

[13] Kirby, Julia., Toward a theory of high performance, Harvard business review 83(7):30-9, 190, July 2005

[14] Rae, D. (2000) "Understanding entrepreneurial learning: A question of how?", International Journal of Entrepreneurial Behaviour and Research, Vol. 6, No. 4, pp. 145-159.

[15] Saroni, Mohammad (2012) Mendidik dan Melatih Entrepeneur Muda Membuka Kesadaran Atas Pentingnya Kewirausahaan bagi Anak Didik. Jogjakarta: Ar-Ruzz Media

[16] Politis, Diamanto, The Process of Entrepreneurial Learning: A Conceptual Framework, Entrepreneurship Theory and Practice 29(4) · July 2005, DOI: 10.1111/j.1540-6520.2005.00091.x

[17] Bailey Gerald D. \& Curriculum Development-A Method to Define Roles, Procedures Volume: 70 issue: 492, page(s): 50-55 Issue published: October 1, 1986, First Published October 1, 1986 Research Article. https://doi.org/10.1177/0192636586070492 12

[18] Evans, Rupert N, \& Edwin, Lewis H. 1978. Foundation of Vocational Education. Columbus. Ohio: Charles E. Merril Publishing Company.Imran MB. Buku Harian Sambas; 1922.

[19] Quintini, G. \& S. Martin (2006) ëStarting well or Losing their Way? The position of Youth in the Labour Market in OECD
Countriesí, OECD Social, Employment and Migration Working Papers Number 39.

[20] Emmerik, I.J. \& Hetty van Arnold B.

Bakker Martin C. Euwema, (2009),"Explaining employees' evaluations of organizational change with the jobdemands resources model", Career Development International, Vol. 14 Iss 6 pp. 594 - 613 Permanent link to this document: http://dx.doi.org/10.1108/13620430910997 312

[21] Stumpf. S.A (2009). Promotion to partnerThe importance of relationship competencies and interpersonal style. Career Development International Vol. 14 No. 5, 2009 pp. 428-440q Emerald Group Publishing Limited 1362-0436

[22] Heinz .W.R (2009). Redefining the Status of Occupations; in Rupert Maclean, David Wilson, Chris Chinien; International Handbook of Education for the Changing World of Work, Bridging Academic and Vocational Learning: Germany: Springer Science+Business Media

[23] Gill, H. (2000). Affective and continuance commitment and their relations with deviant workplace behaviors in Korea. Asia Pac J Manag, 28:595-607.

[24] Wardiman, Djojonegoro. (1998). Pengembangan Sumber Daya Manusia Melalui SMK. Jakarta: Jayakarta Agung Offset

[25] Rojewski. J.W (2009). A Conceptual Framework for Technical and Vocational Education and Training; in Rupert Maclean, David Wilson, Chris Chinien; International Handbook of Education for the Changing World of Work, Bridging Academic and Vocational Learning: Germany: Springer Science+Business Media.

[26] McGrath, Valerie, Reviewing the Evidence on How Adult Students Learn: An Examination of Knowles' Model of Andragogy The Irish Journal of Adult and Community Education, p.99-110 2009 http://www.aontas.com

[27] Creswell, J.W. (2009). Research Design Pendekatan Penelitian Kualitatif, 
Kuantitatif, dan Mixed. Yogyakarta: Pustaka Pelajar. Penterjemah Achmad Fawaid.

[28] Fadaee \& Alzahrh (2014) Explaining the Relationship between Creativity, Innovation and Entrepreneurship TI Journals International Journal of Economy, Management and Social Sciences Vol(3), No (12), December, 2014. www.tijournals.com

[29] Reber, A. S. (1976), "Implicit learning of synthetic languages: The role of instructional set", Journal of Experimental Psychology: Human Learning and Memory, Vol. 2, pp. 88-94.

[30] Johnson, B., \& Wubbenhorst, W., \& Schroeder, C. (2013). Recidivism reduction and return on investment: An empirical assessment of the Prison Entrepreneurship Program. Waco, TX: Baylor Institute for Studies of Religion Special Report.

[31] Shinnar R, \& Pruett M, Toney B. Entrepreneurship education: attitudes across campus. Journal of Education For Business. 2009; 84(3):151-159.

[32] De Carolis DM, \& Saparito P. Social capital, cognition, and entrepreneurial opportunities: a theoretical framework. Entrepreneurship Theory and Practice. 2006; 30(1):41-56.

[33] Shapero, A. \& Sokol, L. The social dimension of entrepreneurship. In The Encyclopedia of Entrepreneurship; Kent, C.A., Sexton, D.L., Vesper, K.H., Eds.; Prentice-Hall: Englewood Cliffs, NJ, USA, 1982.

[34] Gaimon Cheryl \& BaileyJennifer Knowledge Management for the Entrepreneurial Venture, Production and Operations Management, 22 (6), November 2013 DOI: $10.1111 /$ j.19375956.2012.01337.x

[35] Antoncic B, \& Hisrich RD. Privatization, corporate entrepreneurship, and performance: testing a normative model. Journal of Developmental Entrepreneurship. 2003; 8(3):197-218.

[36] Piperopoulos P, \& Dimov D. Burst bubbles or build steam? Entrepreneurship education, entrepreneurial self-efficacy, and entrepreneurial intentions. Journal of Small Business Management. 2015; 53(4):970-985.

[37] Kautonen, Teemu \& van Gelderen, Marco \& Fink, Matthias. 2015. Robustness of the Theory of Planned Behavior in Predicting Entrepreneurial Intentions and Actions. Entrepreneurship Theory and Practice. Volume 39, Issue 3. 655-674. ISSN 10422587 (printed). DOI: 10.1111/etap.12056.

[38] Liñán F, \& Chen Y-W. Development and cross-cultural application of a specific instrument to measure entrepreneurial intentions. Entrepreneurship: Theory and Practice. 2009; 33(3):593-617.

PP Republik Indonesia No 41 tahun 2011 tentang

Pengembangan Kewirausahaan dan

Kepeloporan Pemuda, serta Penyediaan

Prasarana dan Sarana Kepemudaan.

PP Republik Indonesia No 19 tahun 2005 tentang

Standar Nasional Pendidikan

Undang-Undang Republik Indonesia No. 20

Tahun 2003 Tentang Sistem Pendidikan

Nasional

\section{Creative Commons Attribution License 4.0 (Attribution 4.0 International, CC BY 4.0)}

This article is published under the terms of the Creative Commons Attribution License 4.0 https://creativecommons.org/licenses/by/4.0/deed.en_US 